\title{
Ecclesiastical Justice in the Diocese of Coimbra in the 16th Century: Organization, Structure and Jurisdiction*
}

\section{Justicia eclesiástica en la diócesis de Coimbra en el siglo XVI: organización, estructura y jurisdicción}

Jaime Ricardo GOUVEIA

Profesor de Historia Moderna

Universidad Federal de Amazonas. Manaos

orcid 0000-0002-2435-7384

jaim.ricardo@gmail.com

\begin{abstract}
A reorganization of the organisms of justice in the diocese of Coimbra during the first half of the 16 th century culminated in the publication of a Regiment of the Episcopal Court (Auditório), ordered by the bishop of Coimbra D. João Soares in 1547. The prescripts issued by the Council of Trent, intended to reinforce vigilance and regulate and purify the Christian behaviour of prelates, also resulted in a reform of the ecclesiastical judicial system. It was in this context that D. Afonso de Castelo Branco ordered a new Regiment of the Episcopal Court which was published on 3 March, 1592. This normative corpus was central to the operation of the diocese, the rationalization of administrative procedures and the praxis of daily government, and is an invaluable source in the study of episcopal tribunals. By examining the profiles, competences and functions of the various agents who worked there, we will analyze the organization and internal structure of the tribunal of Coimbra.
\end{abstract}

Keywords: Episcopal Court, Regiment, Diocese of Coimbra.
Resumen: La reorganización de los organismos de justicia en la diócesis de Coimbra durante la primera mitad del siglo XVI culminó con la publicación de una Reglamentación del Tribunal Episcopal (Audiencia), ordenada por el obispo de Coimbra D. João Soares en 1547. Las prescripciones del Concilio de Trento, destinadas a reforzar la vigilancia y regular el comportamiento cristiano de los prelados, también dio lugar a una reforma del sistema judicial eclesiástico. Fue en este contexto que D. Afonso de Castelo Branco ordenó un nuevo Regimiento del Tribunal Episcopal que fue publicado el 3 de marzo de 1592. Este corpus normativo fue central para el funcionamiento de la diócesis, la racionalización de sus procedimientos administrativos y la praxis del gobierno cotidiano, y es una valiosa fuente para el estudio de los tribunales episcopales. Al analizar los perfiles, competencias y funciones de los distintos agentes judiciales eclesiásticos, se da cuenta de la organización y de la estructura interna del Tribunal de Coimbra.

Palabras clave: Tribunal episcopal, Regimiento, Diócesis de Coimbra.

* This article benefited from the support of CHAM - The Portuguese Center of Global History (FCSH/NOVA-UAc) through the strategic project sponsored by FCT - Fundação para a Ciência e a Tecnologia, the Portuguese national funding agency for science, research and technology (UID/HIS/04666/2013). 


\section{The Diocesan Tribunals as Mechanisms of Vigilance and Social DisciplinING: Historiographical BalanCE}

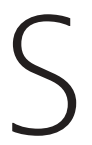
tudies in religious history published in recent decades have shed new light in this field, particularly in certain categories and perspectives of analysis profusely discussed at the European level ${ }^{1}$. New approaches were adopted, particularly in the seventies, and there was a gradual shift from the history of the church to religious history ${ }^{2}$. Another innovation was a series of comparative studies on confessional traditions ${ }^{3}$ and the development of control and social disciplining ${ }^{4}$, which for a long time had been limited to the field of political history ${ }^{5}$. Moreover, in the eighties Wolfgang Reinhard and Heinz Schilling came up with the concept of confessionalization and applied it to religious history to study the close ties between political power and the institutions and agents of religious and ecclesiastical power ${ }^{6}$.

The new perspectives of interpretation that derived from the concepts of confessionalization and social disciplining led to an intensification of studies of religious history in the 16th-18th centuries ${ }^{7}$. Furthermore, the framework of analysis brought about by these concepts generated different and controversial interpretations, not only concerning the efficiency of the mechanisms and agents involved, but also the applicability of the model in some regions of central and

${ }^{1}$ See F. PALOMO, Una bibliografía imperfecta o el análisis fragmentario a treinta años de estudios sobre bistoria religiosa de la Peninsula Ibérica en los siglos XVI-XVIII, Lusitania Sacra 21 (2009) 173-235.

2 See K. Thomas, Religion and the Decline of Magic: Studies in popular beliefs in sixteenth and seventeenth century England, Penguin Books, Harmondsworth 1973; J. Delumeau, Le Catholicisme entre Luther et Voltaire, Presses Universitaires de France, Paris 1971.

3 See P. Benedict, What is Post-Confessional Reformation History, Archive for Reformation History 97 (2006) 277-283.

${ }^{4}$ See G. Oestreich, Neostoicism and the Early Modern State, Cambridge University Press, Cambridge 1982 .

${ }^{5}$ See H. BiAnchi - M. SimONDi - I. TAYlor (eds.), Deviance and control in Europe: papers from the European Group for the Study of deviance and Social Control, John Wiley and Sons, London 1975.

${ }^{6}$ See W. ReINHARD, Reformation, counter-reformation, and the Early Modern State: a reassessment, The Catholic Historical Review 753 (1989) 383-404; W. ReInHARD, Pressures towards Confessionalization? Prolegomena to a Theory of the Confessional Age, en S. Dixon (ed.), The German Reformation: The Essential Readings, Blackwell Publishing, Blackwell 1999, 169-192; W. REINHARD, Disciplinamento sociale, confessionalizzazione, modernizzazione. Un discorso storiografico, en P. PRODI (ed.), Disciplina dell'anima, disciplina del corpo e disciplina della società tra medioevo ed età moderna, Società editrice il Mulino, Bologna 1994, 101-123; H. SchILling, Religion, Political Culture and the Emergence of Early Modern State. Essays in German and Dutch History, E. J. Brill, Leiden 1992.

7 See H. Roordenburg - P. Spierenburg (eds.), Social Control in Europe, 1500-1800, 2 vols., Ohio 2004, 1: 1-22; E. Rummel, The Confessionalization of Humanism in Reformation Germany, Oxford 2000. 
northern Europe, and its susceptibility to failure in other European spaces ${ }^{8}$. Despite the definite proximity and similarity of the procedures experienced in Catholic and Protestant territories ${ }^{9}$, we should not overlook the differences, and try to understand how measures that were impelled from the top of the hierarchy were subject to adaptation and negotiation in the various societies ${ }^{10}$.

Despite the number of ecclesiastical tribunals of first instance that existed during the period under study, namely the diocesan tribunals or Episcopal Courts (Auditórios), tribunals of the religious orders, the Inquisition, the Tribunal of the Legation (Tribunal da Legacia) or Nunciature, little work has been done in Portuguese historiography on social disciplining through religious courts. In the last thirty years more attention has been given to studying the Inquisition, while other institutions with a strong presence and disciplinary capacity in society have been overlooked ${ }^{11}$. In addition to the Holy Office, bishops, religious orders, and the respective judicial instances were fundamental centers for the organization of the modern religious arena. Although they have mostly been studied separately, historiography has seen a gradual increase in interest in their joint activity ${ }^{12}$. This question has been addressed in depth in a book written by José Pedro Paiva in which he sustains that in modern Portugal inquisitors and bishops worked jointly in assuming the role of bastions of faith and discipline ${ }^{13}$. Apart from the inquisitorial tribunals, the inquiries ca-

${ }^{8}$ See J. P. Parva, El Estado en la Iglesia y la Iglesia en el Estado. Contaminaciones, dependencias y disidencia entre la monarquía y la Iglesia del reino de Portugal (1495-1640), Manuscrits 25 (2007) 4557; L. Roper, Allegiance and Reformation History, Archive for Reformation History 97 (2006) 289-297; E. F. SHaGan, Can Historians End the Reformation?, Archive for Reformation History 97 (2006) 298-306; BENEDICT XVI, Confessionalization in France? Critical reflections and new evidence, en A. R. MENTZER - A. SPICER (eds.), Society and Culture in the Hugenot World, 1559-1685, Cambridge University Press, Cambridge 2001, 44-61; J. R. FARR, Confessionalization and Social Discipline in France, 1530-1685, ARG 94 (2003) 276-293; S. HENDRIX, Post-Confessional Research and Confessional Commitement, Archive for Reformation History 97 (2006) 284-287.

9 See J. Headley - J. Hillerbrand - A. J. Papalas (eds.), Confessionalization in Europe, 15551700. Essays in honour and memory of Bodo Nischam, Ashgate, Burlington 2004, 17-25.

10 See F. Palomo, A Contra-Reforma em Portugal, 1540-1700, Temas e Debates, Lisboa 2006.

11 See F. Palomo, A Contra-Reforma..., cit., 30-31. For the main contributions in this area see J. R. GouveIa, A Quarta Porta do Inferno. A vigilância e disciplinamento da luxúria clerical no espaço lusoamericano, 1640-1750, Chiado Editora, Lisboa 2015, 66-76. However, due to its scope, and the fact that it is largely a result of the above mentioned tendency in recent decades, I must acknowledge the first History of the Portuguese Inquisition: G. MARCOCCI - J. P. PAIVA (eds.), História da Inquisição Portuguesa, 1536-1821, Esfera dos Livros, Lisboa 2013.

12 For a critical review of the works about the articulation between powers in the religious field see J. R. GOUvEIA, A Quarta Porta..., cit., 76-81.

13 See J. P. Parva, Baluartes da fé e da disciplina. O enlace entre a Inquisição e os bispos em Portugal, 15361750, Imprensa da Universidade de Coimbra, Coimbra 2011. 
rried out by bishops during pastoral visits, an indispensable instrument for the government of the dioceses, have also been the focus of important studies ${ }^{14}$.

Finally, we should consider the attention given by Portuguese and Brazilian historiography to the operation of the Episcopal Courts as institutions of vigilance and social disciplining. In his work about the History of the Church in Portugal, Fortunato de Almeida fails to address the operation of the structures of the episcopal government, and he does not mention the existence of the various diocesan tribunals ${ }^{15}$.

A more recent work, the História Religiosa de Portugal edited by Carlos Moreira de Azevedo, dedicates a chapter to dioceses and ecclesiastical organization, and José Pedro Paiva briefly gives an important view of how the diocesan bureaucracy and administrative mechanisms functioned. This author summarizes some of the ideas that figure in another article he wrote for the magazine Lusitania Sacra where he analyses the diocese of Coimbra ${ }^{16}$. The ecclesiastical tribunals were the focus of analysis in an article by José Silva published in the Dicionário de História Religiosa de Portugal, which is generalized and contains some inaccuracies ${ }^{17}$. Another author, António Manuel Hespanha

${ }^{14}$ See J. P. PaIva, La réforme catholique au Portugal - les visites pastorales des évêques, Arquivos do Centro Cultural Calouste Gulbenkian XLIII (2002) 159-175; J. P. PAIVA, Visitações, en C. M. AzEvEDo (ed.), Dicionário de História Religiosa de Portugal, Círculo de Leitores e Centro de Estudos de História Religiosa, Lisboa 2001, P-V-365-370; J. P. PAIVA, As visitas pastorais, en C. M. AzEvEDo (ed.), História Religiosa de Portugal, 3 vols., Círculo de Leitores, Lisboa 2000, 2: 250-255; J. P. PAIVA, Inquisição e Visitas Pastorais. Dois mecanismos complementares de controlo social?, Revista de História e Teoria das Ideias 11 (1989) 85-102; J. CARVALHO, As visitas pastorais e a sociedade de Antigo Regime. Notas para o estudo de um mecanismo de normalização social, Coimbra 1985; J. CARVALHO, A jurisdição episcopal sobre leigos em matéria de pecados públicos: as visitas pastorais e o comportamento moral das populações portuguesas de Antigo Regime, Revista Portuguesa de História XXIV (1988) 121-163; J. CARVALHO, Comportamentos morais e estruturas sociais numa paróquia de Antigo Regime: Soure, 1680-1720: reconstituições, interpretações e metodologias, Faculdade de Letras, Coimbra 1997; J. P. PAIVA - J. R. CARVALHO, A evolução das visitas pastorais da diocese de Coimbra nos séculos XVII e XVIII, Ler História 15 (1989) 29-41; B. LEAL, La crosse et le batôn, Gulbenkian, Paris 2004; F. N. SOARES, A arquidiocese de Braga no século XVII. Sociedade e mentalidades pelas visitações pastorais - 1550-1700, Universidade do Minho, Braga 1993; M. A. F. Lú́s, Visitas Pastorais ao concelho da Lourinhã no século XVII, Lusitania Sacra 23 (2011) 169-187.

15 See F. AlmeIDA, História da Igreja em Portugal, Portucalense Editora, Livraria Civilização Editora, Porto 1968-1971, 5 vols.

${ }^{16}$ See J. P. PaIVA, Dioceses e organização eclesiástica, en C. M. AzEvedo (ed.), História Religiosa de Portugal, ed. Carlos Azevedo, 3 vols., Círculo de Leitores, Lisboa 2000, 2: 187-199; J. P. PAIVA, A administração diocesana e a presença da Igreja. O caso da diocese de Coimbra nos séculos XVII e XVIII, Lusitânia Sacra 2a-3 (1991) 71-110.

17 See J. A. Silva, Tribunais Eclesiásticos, en C. M. Azevedo (ed.), Dicionário de História Religiosa de Portugal, 4 vols., Círculo de Leitores e CEHR, Lisboa 2001, 4: 303-305. 
makes an analytical summary in his work Poder e as Instituições no Antigo Regime of ecclesiastical jurisdiction from a legal perspective ${ }^{18}$. The only monograph specifically dedicated to the analysis of an Episcopal Court appeared in 2003, written by Ana Trindade and Dulce Teixeira, and is centred on the Regimento of the Episcopal Court of Funchal and several proceedings found in the documental archives of that tribunal ${ }^{19}$.

Moreover, in 2005 José Viriato Capela published a small study on the end of temporal jurisdiction in Braga during the government of Archbishop D. Frei Caetano Brandão. Despite some inaccuracies the article addresses important issues such as the impact of reforms in ecclesiastical courts during the 18 th century ${ }^{20}$.

One year later, João Rocha Nunes wrote an article in which he analyzed the activity of the Episcopal Court of Viseu between 1684 and 1689, based on a book from the Ecclesiastical Chamber with records of sentence summaries. This is a pioneer analysis which offers an insight into the main activities of this key ecclesiastical organism, but leaves other issues open because of a shortage of documents ${ }^{21}$.

A further article in which I analyze the interrogation ordered by D. Miguel da Anunciação in 1741 to be carried out by the diocesan tribunal of Coimbra, reveals that these judicial organisms had mechanisms of internal discipline to purge possible unlawfulness and corruption ${ }^{22}$. Later, in a more comprehensive study entitled A Quarta Porta do Inferno. A vigilância e disciplinamento da luxúria clerical no espaço luso-americano (1640-1750) which addresses clerical lasciviousness, I dedicated a few chapters to a comparative analysis of Episcopal Courts in the Portuguese kingdom with some in the Brazilian colony between 1640 and 1750. I concluded that the structures of diocesan tribunals in Portugal were transferred to the other side of the Atlantic with few alterations ${ }^{23}$.

18 See A. M. Hespanha, Poder e Instituições no Antigo Regime, Edições Cosmos, Lisboa 1992, 43-44, 56-57.

19 See A. Trindade - D. TeixeIRA, O Auditório Eclesiástico da Diocese do Funchal. Regimento e espólio documental do século XVII, Instituto Superior de Administração e Línguas, Funchal 2003.

20 See J. V. CAPELA, O Auditório Eclesiástico Bracarense e o fim da sua jurisdição temporal. O papel do arcebispo D. Frei Caetano Brandão, Bracara Augusta 108-121 (2005) 13-21.

${ }^{21}$ See J. R. NunEs, Crime e castigo: pecados públicos e disciplinamento social na Diocese de Viseu (16841689), Revista de História da Sociedade e da Cultura 6 (2006) 177-213.

22 See J. R. GOUVEIA, Quod non est in actis, non est in mundo: mecanismos de disciplina interna e externa no Auditório Eclesiástico de Coimbra, Revista do Centro de História da Sociedade e da Cultura 9 (2009) 179-204.

23 See J. R. GouveIA, A Quarta Porta do Inferno..., cit., 325-342, 471-481. 
Shortly before, I had published an article entitled Os ladrões das honras e a repressão das desonras. A ação do fuízo Eclesiástico no Atlântico português (1640-1750) in the magazine Ultramares. This comparative analysis focused on the bishoprics of Coimbra, Maranhão and the captaincy of Minas, and addressed two questions: the actions undertaken on both sides of the Portuguese Atlantic by the diocesan judicial governing structures in terms of non-heresiarch clerical lisciviousness, and the impact of this action in the above mentioned territories $^{24}$.

Finally, there is a relevant article by Federico Palomo which examines some facts about the operation of ecclesiastical justice in the archbishopric of Évora ${ }^{25}$, and recently José Pedro Paiva analyzed the structures and the action of the episcopal court of Viseu between the sixteenth and nineteenth centuries through the few sources that still exist ${ }^{26}$.

Turning our focus now to Brazilian historiography, it has to be said that the study of mechanisms of vigilance and disciplining of Christianity has been very incipient ${ }^{27}$. In 1993 Luis Carlos Villalta was one of the first authors to use documents from the Ecclesiastic Justice. Based on an analysis of sentences issued by the diocesan tribunal of Mariana, he wrote a master's dissertation on methods of punishment and rules regarding sexuality in the day-to-day society of Minas Gerais ${ }^{28}$.

In 1998 Marilda Silva defended a masters dissertation which examined the role of women in the Ecclesiastical Justice of the bishopric of Mariana between 1748 and 1830. The thesis was published in 2001, after she had previously published an article in the Revista História Social where she summarized some of the main arguments of her thesis and revealed a blatant incohe-

${ }^{24}$ See J. R. GouveIA, Os ladrões das honras e a repressão das desonras. A ação do fuízo Eclesiástico no Atlântico português (1640-1750), Revista Ultramares 4-1 (2013) 45-71.

25 See F. PALOMO, La autoridad de los prelados tridentinos y la sociedad moderna. El gobierno de don Teotónio de Braganza en el arzobispado de Évora (1578-1602), Hispania Sacra 47 (1995) 587-624.

${ }^{26}$ See J. P. PaIVA, As estruturas do governo diocesano, en J. P. Parva (ed.), História da Diocese de Viseu, Diocese de Viseu e Imprensa da Universidade de Coimbra, vol. 2 (1505-1819), Viseu 2016, 206224.

27 See E. HoornaerT - R. AZZI - K. V. D. GRIJP - B. Brod, História da Igreja no Brasil, Editora Vozes, Petrópolis 1977; E. Hoornaert, A Igreja no Brasil - colónia, 1550-1800, 3th ed., Editora Brasiliense, S. Paulo 1994 (first edition was published in 1982), 12-22; J. LacomBE, A Igreja no Brasil Colonial, en S. B. Holanda (ed.), História Geral da Civilização Brasileira, 11 vols., Difel, S. Paulo 1977, I, 2.

${ }^{28}$ See L. C. Villalta, A torpeza diversificada dos vícios: celibato, concubinato e casamento no mundo dos letrados de Minas Gerais, 1748-1801, Master diss., São Paulo University 1993. 
rence between ecclesiastical and inquisitorial jurisdiction. The allegation that in reality civil society was more concerned with maintaining order, justice, and disciplining, and used the Tribunal as an instrument, lacks a plausible explanation, particularly because the tribunals were not only instruments used by Christianity, but also a mechanism that acted over it. An examination of the accusations received by the Auditório following the pastoral visits would lead to different conclusions ${ }^{29}$.

Two years later another work was published based on diocesan judicial sources which studied the social phenomena that led to the production of certain records of that instance of the government. Marcia Krinski focused her analysis on marriage vows and promises, presenting at the end a series of transcripts of judicial documents from the Ecclesiastical Justice of S. Paulo. The transcripts were not accompanied, as would have been required, by the study of certain documents, like autos de esponsais (betrothment), autos de justificação entre partes (defense by one of the parties) and autos de perguntas (inquests). However, the dissemination of the documental archives that ensued with the release of the book must be acknowledged ${ }^{30}$.

In 2007 Bruno Feitler published a book which didn't focus exclusively on the structure and policies of the Ecclesiastical Justice, but rather presented an overview of the ways in which the different mechanisms of religious and social control interacted with each other and with the society of Northeast Brazil. This is a significant contribution in understanding how the Brazilian dioceses were structured judicially ${ }^{31}$.

In 2008 Fabricio Santos completed his master's thesis about conflicts between the clergy and parishioners in Curitiba and Paranaguá. This author was one of the few who until then had attempted to analyze the criminal proceedings from the Archive of Dom Leopoldo Duarte in the state of São Paulo, which are currently in the care of the Universidade Federal do Paraná. Although he admits that vicariates forane were inferior and peripheral

${ }^{29}$ See M. S. SILVA, Normas e padrões do tribunal eclesiástico mineiro (1750-1830) e o modo de inserção das mulberes neste universo jurídico, História Social 7 (2000) 99-118; M. S. SILVA, Dignidade e transgressão: mulheres no Tribunal Eclesiástico em Minas Gerais, 1748-1830, Editora da UNICAMP, Campinas 2001.

30 See M. L. KRINSKi (ed.), Promessas desfeitas: documentação paranaense em processos do fuizo Eclesiástico da Diocese de São Paulo, 1750-1796, Aos Quatro Ventos, Curitiba 2003.

31 See B. Feitler, Nas malhas da consciência. Igreja e Inquisição no Brasil. Nordeste, 1640-1750, Alameda, Poebus, S. Paulo 2007. 
judicial sub-units, he doesn't mention their subordination to the Episcopal Court $^{32}$.

That same year the first attempt was made to thoroughly study the mechanisms of government of a Brazilian bishopric. Maria do Carmo Pires embarked on an analysis of the Ecclesiastical Justice of the bishopric of Mariana between 1748 and 1800. However, her attempt to appraise the functions and competences of the officials/officers through the normative corpuses turned out to be incipient. The book has substantial interpretive limitations, partly because her sources were limited to only one of the Brazilian Auditórios, and partly because of the scant Portuguese bibliography ${ }^{33}$.

The studies published at the beginning of this decade are the ones that have most marked the field. Not only because of the use of theoretical and methodological tools that are better suited to so-called scientific historical work, but especially because they derive from solid research hypotheses and formulation of problems, which ocurr, largely, from contact with historians, historiographies and historical sources on both sides of the Atlantic.

The first consistent study done of the Episcopal Courts in colonial Brazil is owed to Pollyanna Muniz. In her doctoral thesis about the secular clergy and the Episcopal Court of Maranhão in the 18th century, she examines the bureaucratic structure and operation of the tribunal, extending her analysis to the sociology of its agents, relations with the spheres of power (namely in terms of collaboration, conflict, and appeals and grievances), and she examines the population involved in the judicial network ${ }^{34}$. Another work by this author was an innovative study published in 2011 where she underlines the importance of the documents produced by the Auditório of the bishopric of Maranhão. This corpus was important to examine the daily life of Maranhão society, to perceive the concerns of ecclesiastical authorities (even in long periods of office vacancy), to understand the attitudes and behavior of laymen and clergy, to perceive what crimes came under the jurisdiction of this Tribu-

32 See F. F. SANTOS, Conflitos setecentistas: sociedade e clero nas vilas de Curitiba e Paranaguá, Master diss., Paraná University, 2008.

33 See M. C. PIRES, Juizes e Infratores. O Tribunal Eclesiástico do Bispado de Mariana, 1748-1800, ANNABLUME Editora, S. Paulo 2008.

${ }^{34}$ See P. G. MunIz, Parochos imperfeitos: Fustiça Eclesiástica e desvios do clero no Maranhão colonial, $\mathrm{PhD}$. diss., Federal Fluminense University, 2011. 
nal, and the degree of penetrability of ecclesiastical justice beyond the periodic pastoral visits ${ }^{35}$.

The following year the same author published an article in the magazine Tempo about infringements by religious orders, based on documents from the Overseas Council and lawsuits against the regular clergy filed by the Episcopal Court of Maranhão. Before then nothing had been written about this subject $^{36}$.

More recently, in 2013, two new contributions were made to this field by Patrícia Santos. Firstly, in her doctoral thesis she analyzed the collaboration, competition and conflict between secular and ecclesiastical authorities in the auriferous region of Minas Gerais before and after the creation of the bishopric of Mariana ${ }^{37}$. Secondly, that same year she published an article whereby she examined the structures and circuits of the Episcopal Courts of Coimbra and Mariana. From a perspective of crossed history, she analyzed the complaints, disputes and accusations, and concluded that they were structurally similar in both dioceses ${ }^{38}$.

The book entitled Inquisição e fustiça Eclesiástica by Yllan de Mattos and Pollyanna Muniz, and published in 2013 assembled a series of articles that for the first time in historiography attempted a joint perspective of two of the most important Catholic judicial centers of the modern period. However, in the book there was a huge gap between the analytical approach to Brazil and other latitudes of the Portuguese empire and the actual metropolis ${ }^{39}$.

A year later there were new editorial initiatives. Pollyanna Mendonça wrote an article for one of the first issues of the magazine Fontes about the documental archives of the Episcopal Court of Maranhão. She discussed their

${ }^{35}$ See P. G. MuNIZ, O tribunal episcopal do bispado do Maranhão: dinâmica processual e jurisdição eclesiástica no século XVIII, en B. FEITLER - E. S. SouZA (eds.), A Igreja no Brasil. Normas e práticas durante a vigência das Constituições primeiras do Arcebispado da Baía, UNIFESP, S. Paulo 2011, 481506.

${ }^{36}$ See P. G. MunIZ, Ordens religiosas e transgressão no Maranhão colonial, Tempo 16-32 (2012) 115136.

37 See P. F. SANTOS, Carentes de justiça: juizes seculares e eclesiásticos na «confusão de latrocínios» em Minas Gerais, 1748-1793, PhD. diss., São Paulo University, 2013.

38 See P. F. SANTOS, A justiça eclesiástica e os mecanismos de busca de infratores: as queixas, as querelas e as denúncias no século XVII, Boletim do Arquivo da Universidade de Coimbra 26 (2013) 137-160.

39 See Y. Mattos - P. G. Muniz (eds.), Inquisição e fustiça Eclesiástica, Paco Editorial, S. Paulo 2013. 
value as historical sources and showed their analytical potential ${ }^{40}$. At the same time, this author, together with Yllan de Mattos, wrote a study of the limits and complementarities between Ecclesiastical Justice and the Inquisition in Portuguese America ${ }^{41}$.

The documents of the Ecclesiastical Justice have served, albeit rather sporadically, for studies of a non-institutional nature. For example, in 2015 William Martins published an article about the procedures for executing wills in the Episcopal Court of Rio de Janeiro between 1720 and 1808. He examined the control and execution of testamentary bequests, a matter of mixed jurisdiction. This analysis is well consolidated in terms of bibliography and documentation, but needs a more substantiated examination regarding the way the exercise of the law alternated between secular and ecclesiastical justices. It also calls for a full review of the bureaucratic organisms and circuits of the Ecclesiastical Justice, and the procedural steps ${ }^{42}$.

An article by Aldair Rodrigues was recently published in the E-journal of Portuguese History further developing some of the ideas he had defended in his doctoral thesis (also recently published in the form of a book). Through an analysis of the vicariates forane and the profile of their main officer, this author explains how the diocesan structures took root in Minas Gerais and São Paulo. He clarifies how the mechanisms were organized and what function they fulfilled in the episcopal administration ${ }^{43}$.

A master's dissertation is currently underway about the Episcopal Court of São Paulo between 1747 and 1822, under the authorship of Michelle de Britto. She published some preliminary conclusions in the annals of the 28th National History Symposium of ANPUH which took place in Florianopolis ${ }^{44}$.

40 See P. G. MunIZ, Os processos da Igreja: documentos do Tribunal Episcopal enquanto fonte histórica, Fontes 1-2 (2014) 15-27.

${ }^{41}$ See Y. MatTos - P. G. Muniz, Vigiar a ortodoxia: limites e complementaridades entre a fustiça Eclesiástica e a Inquisição na América Portuguesa, Revista de História 171-2 (2014) 287-316.

42 See W. S. MarTins, Contas testamentárias: a justiça eclesiástica e a execução de testamentos no Rio de Faneiro (c. 1720-1808), en R. GUEDES - C. RODRIGUES - M. WANDERLEY (eds.), Últimas vontades. Testamento, sociedade e cultura na América Ibérica (séculos XVII e XVIII), Mauad Editora, Rio de Janeiro 2015.

43 See A. C. Rodrigues, Clergy, Society and Power Relations in Colonial Brazil: on the Vicar Forane (vigário da vara), 1745-1800, E-journal of Portuguese History 13-1 (2015) 40-67; A. C. RoDRIGUES, Igreja e Inquisição no Brasil. Agentes, carreiras e mecanismos de promoção social - século XVIII, Alameda, S. Paulo 2014, 283-341.

${ }^{44}$ See M. C. Britto, A atuação do Tribunal Episcopal do bispado de S. Paulo. Delitos e fustiça Eclesiástica na Colonia (1747-1822), en Anais Eletrónicos do XXVIII Simpósio Nacional de História, Lugares dos historiadores: velhos e novos desafios, ANPUH, Florianopolis 2015, 1-12. 
In Spanish historiography progress has been made to determine the activities of ecclesiastical tribunals in Spanish territories ${ }^{45}$, and in Italy little has been written on this subject ${ }^{46}$.

It can be concluded that despite the ongoing progress of historiography in the field to which this study is dedicated, it has focused in recent years on carrying out a work that is tendentiously more multifaceted since it analyses both sides of the Atlantic, many aspects are still unknown about the operation of the Luso-American Ecclesiastical Courts. This includes strategies for action and respective results, common offenses and their punishment, procedures, financial backing of the tribunals and the impact on Christian behavior. Also, little is known about the relationship between these tribunals and other judicial instances, how they influenced diocesan life, and whether they were always careful about the implementation of justice. Finally, there is limited knowledge of the profiles required of the officers of justice and the competences that were attributed to them.

${ }^{45}$ See I. P. MuÑoz, Pecar, delinquir y castigar: el Tribunal Eclesiástico de Coria en los siglos XVI y XVII, Institución Cultural «El brocence», Diputación Provincial de Cáceres, Salamanca 1992; M. L. Candau Chacón, Los delitos y las penas en el mundo eclesiástico sevillano del XVIII, Diputación Provincial, Sevilla 1993; M. L. CANDAU CHACón, Delito sexual y justicia eclesiástica en los Tiempos Modernos, en J. I. Fortea - J. E. GELABERT - T. A. MANTECón (eds.), Furor et rabies. Violencia, conflicto y marginalización en la Edad Moderna, Servicio de Publicaciones de la Universidad de Cantabria, Santander 2004, 410-411; J. L. DE LAS Heras SANTOS, La criminalidad femenina ante la justicia episcopal en la Salamanca del siglo XVII, en I. M. R. D. BraGa - M. T. HernándeZ (eds.), As mulheres perante os tribunais do Antigo Regime na Península Ibérica, Imprensa da Universidade de Coimbra, Coimbra 2015, 85-109; R. S. RuBIO, Instituciones y poderes eclesiásticos en la Extremadura de finales del siglo XVIII, Norba 3 (1985) 113-125; C. TRASELLI, Du fait divers à l'bistoire sociale. Criminalité et moralité en Sicile au debut de l'epoque moderne, Annales E.S.C. 28 (1973) 226-246.

${ }^{46}$ Noteworthy are the following: S. SEIDEL - D. QUagLioni (eds.), I tribunali del matrimonio (secoli XV-XVIII), Il Mulino, Bologna 2006; G. BONACCHI, Legge e peccato. Anime, corpi, giustizia alla corte dei papi, Laterza, Roma-Bari 1995; L. FERRANTE, La sessualità come risorsa. Donne davanti al foro arcivescovile di Bologna (séc. XVII), Mélanges de l'École française de Rome 99-2 (1987) 989-1016; L. FERRANTE, “"Malmaritate" fra assistenza e punizione (Bologna sec. XVI-XVII)», en Forme e soggetti dell'intervento assistenziale in una città di antico regime, Il Mulino, Bologna 1986, 65-109; O. D. Simplicio, Peccato, Penitenza, Perdono. Siena 1575-1800. La formazione della coscienza nell'Italia moderna, Franco Angeli, Milano 1994, 59165. See also some chapters of A. Prosperi, Tribunali della conscienza. Inquisitori, confessori, missionari, Einaudi, Torino 1996, 219-335; and P. Prodi, Disciplina dell' anima, disciplina del corpo e disciplina della società tra medioevo ed età moderna, Società editrice il Mulino, Bologna 1994. 


\section{Episcopal Courts (Auditórios) in the Portuguese Atlantic}

In the framework of the ecclesiastical judicial hierarchy, the Auditorios, important pillars of diocesan judicial power, were merely ordinary tribunals of the first instance $(A q u o)^{47}$. The second instance (Ad quem), comprised the Relações Eclesiásticas (Courts of Appeals), with headquarters in the main metropolitan dioceses: Lisbon, Evora and Braga in Portugal; Goa (after 1557) and Bahia (after 1676) in the colonial territories. The third instance comprised the Nunciature or Legacia (Legation Tribunal), which had jurisdiction of second instance in causes pertaining to metropolitan dioceses and to exempti nullius diocesis. It was possible to appeal a decision of the religious tribunals in a secular court, namely the Tribunal da Relação (Royal High Court) and the Casa da Suplicação (Court of Appeal). It was also possible to appeal a judicial decision to the Apostolic See ${ }^{48}$.

The jurisdiction of the Episcopal Courts on both sides of the Atlantic dealt, according to the language of the time, with two distinctive situations: by reason of the person (ratione personae), and by reason of the subject matter (ratione materiae). In the first case the courts had jurisdiction over all secular clergy. In the second case, that is, the nature of the offenses, it had competences to try anyone who committed public sins, whether they were laymen or clerics. The antistes had causae mixti fori competences, not bound exclusively to one Tribunal ${ }^{49}$.

The ecclesiastic judicial system was a hierarchic network of tribunals where the application of the Law was based on constitutions and compilations of cannon law ${ }^{50}$. The first known Regiment of an Episcopal Court is the one ordered in Evora in 1535 by bishop D. Afonso. It circulated as a manuscript,

47 See J. P. PaIVA, Dioceses..., cit., 187-199.

48 Told to us by F. AlmeIDA, História da Igreja..., cit., 2: 231-236. However, there are not sufficient studies to clarify the type of court of appeals existed and in what molds it what possible to appeal. On procedures for the Tribunal da Legacia (Legation Tribunal) see G. M. CAMINHA, Tratado da Forma dos Libellos, Oficina dos Irmãos e Sobrinho Ginioux, Coimbra 1764, 152-157.

49 See F. AlmeIda, História da Igreja..., cit., 2: 231-236; A. M. HesPanha, Poder e Instituições..., cit., 43-44, 56-57; J. A. SILVA, Tribunais Eclesiásticos..., cit., 303-305; Enciclopedia de la Religión Católica, Dalmau y Jover, S. A., Barcelona 1956, 7: 352; T. T. ZwI (ed.), New Catholic Encyclopedia, New York, 14: 284-287; Enciclopedia Cattolica, Casa Editrice G. C. Sansoni, Firenze 1954, 12: 495-510. See also, on concordats, G. P. DE CASTRO, Monomachia sobre as concórdias que fizeram os reis com os prelados de Portugal nas dúvidas da jursidição eclesiástica e temporal, José Francisco Mendes, Lisboa 1738 .

${ }^{50}$ See F. AlmEIDA, História da Igreja..., cit., 2: 231-236. 
and various addendums were made to it in 1565 during the administration of archbishop D. João de Melo. Following the Council of Trent, almost all the dioceses, including those overseas, published their regiments of the courts in print, usually in editions of the Constituições Sinodais ${ }^{51}$.

Apart from defining the composition of the tribunals, these regiments established the profile and competences of the various officers and determined certain aspects of the praxis of daily administration, namely the procedures of court hearings, sanctions imposed on offending officials, procedures of summary cases, course of action in cases of suspicion against officials of the Episcopal Court, embargoes and grace periods in pending causes ${ }^{52}$.

In Brazil, bishoprics were only granted their own ecclesiastical legislation in the first decade of the 18th century. Until then they had been entirely governed by the normative codes of the archbishopric of Lisbon. Furthermore, the Regimento do Auditório Eclesiástico and the Primeiras Constituições do arcebispado da Babia, dating from 1704 and 1707 respectively, did not introduce any major alterations in the structure of the organisms of episcopal justice $^{53}$.

The bishop was the highest figure in the diocesan administration. When the See was vacant other officers presided over the Tribunal, although some regiments, were negligent in this matter ${ }^{54}$. Apart from relying on the prelate, the Ecclesiastical Justice counted on various other agents whose competences were similar in the bishoprics of the metropolis and those of the Brazilian colony ${ }^{55}$.

The activity of the Episcopal Courts in Portugal and in the colonies was carried out in four ways: general interrogations (devassas gerais), special interro-

${ }^{51}$ See J. P. PAIVA, Dioceses..., cit., 187-199; J. P. PAIVA, The Portuguese secular clergy in the sixteenth century and seventeenth centuries, en E. ANDOR - I. G. TóTH (eds.), Frontiers of Faith. Religious Exchange and the Constitution of Religious Identities, 1400-1750, Central European University, European Science Foundation, Budapest 2001, 157-166.

52 See Regimento dos officiaes do Auditorio Ecclesiastico do bispado de Coimbra, Antonio de Mariz, impressor da Universidade, Coimbra 1592; J. P. PAIVA, Dioceses..., cit., 187-199; J. P. PAIVA, The Portuguese secular clergy, 157-166.

53 For a more in-depth study of this question, see J. R. GouveIA, A Quarta Porta do Inferno..., cit., 174-185.

54 See Regimento dos officiaes..., cit., fol. 1-2v. See also J. R. Nunes, Crime e castigo..., 177-213; P. G. MunIz, O tribunal episcopal..., cit., 5; P. F. SANTOS, Carentes de justiça..., cit., 178-179.

55 See Regimento dos officiaes..., cit.; Regimento do Auditorio Ecclesiastico do arcebispado da Babia, Metropoli do Brasil e da sua Relaçam e officiaes da justiça ecclesiastica e mais cousas que tocão ao bom governo do dito arcebispado, Oficina de Pascoal da Silva, Lisboa Ocidental 1718. 
gations (devassas especiais), disputes (querelas) and accusations ${ }^{56}$. Of all the common causes, only matrimonial, beneficial (beneficiais), and criminal between parties (criminais entre partes) could be dispatched in the Ecclesiastical Chamber ${ }^{57}$.

Contestation of judicial officers was provided for in the regiments of the Episcopal Courts, but this implied delays in trials. In order to prevent the defendants from appealing to other tribunals, the Auditórios required a deposit in their treasuries at the time of the petition to cover the costs incurred by the deferment. If the accused was poor, the payment was moderate. If it was proven that the defendant's suspicions regarding a particular officer were wellfounded, the money would be returned. If the opposite was true, they lost this money and they had to pay an additional penalty that was stipulated in the sentence. For the accusations to be accepted they had to be written by one of the lawyers of the Auditorio and presented by a registrar or an apostolic notary to the same Tribunal. Before the sentence was determined, the defendant was taken to the audience chamber where he was informed of the nature of the accusations made against him, as well as the name of the claimants, because he had the right to another hearing. Definitive sentences could only be commuted by the bishop, and in more serious cases, it was sometimes necessary to obtain a bull of absolution.

The procedural practice of the Episcopal Courts could differ according to each offense, but always took place in the same format according to whether the defendants were laymen or clergy. Procedures only differed among summary causes, which were dealt with swiftly, and ordinary causes, which required other formalities like «libelo (indictment), contestação da lite (appeal), conclusão da causa (closing the cause)», among others. The numerous articles and «feitos» (steps involved in a legal process) varied in number from one case to another ${ }^{58}$.

${ }^{56}$ See Regimento dos officiaes..., cit.; Regimento do Auditorio Ecclesiastico do arcebispado da Babia..., cit.; A. V. Cabral, Pratica judicial muyto util e necessaria para os que principiam os officios de julgar, e advogar, e para os que solicitão causas nos auditorios de hum e outro foro tirada de varios autores practicos e dos estylos mais praticados nos auditórios, Officina de Carlos Esteves Mariz, Lisboa Ocidental 1740, 94. On the different routine formalities, moments and deadlines during the proceedings, as well as the officials responsible for those tasks see J. R. GouveIA, A Quarta Porta do Inferno..., cit., 174-185.

57 See Regimento dos officiaes..., cit., fol. 6-6v.

${ }^{58}$ For a more in-depth study of this question, see J. R. GouvEIA, A Quarta Porta do Inferno..., cit., 174-185. It is indespensible, in this framework, to again consult P. G. MunIz, O tribunal episcopal..., cit. 
Court hearings were to take place regularly and all the officers were required to be present. These could be fined and suspended in the case of contempt of court ${ }^{59}$. According to some studies, punishment varied little and went from fines, end of term or oath of amendment, to loss of the right to exercise certain functions inherent to the ecclesiastical ministry, or even prison and exile. Sanctions were much heavier for clerics than for laymen, which caused some defendants to appeal for commutation. Definitive sentences could only be commuted by the bishop, and in more serious cases, it was sometimes necessary to obtain a bull of absolution ${ }^{60}$.

The ecclesiastical tribunals did not possess temporal coercive power. To apply coercive measures they had to ask the secular arm and make a petition to the relevant territorial judge, which sometimes resulted in conflicts, especially when the defendants were secular judicial officers ${ }^{61}$.

In the Brazilian colony the instances of diocesan judicial administration had more difficulty in fulfilling their duties efficiently because of the bond to royal patronage ${ }^{62}$. The slowness of communications with the crown, whose corroboration was required in the decision-making process, often presented an obstacle ${ }^{63}$. The crown was informed and asked for consent for decisions such as the need to substitute an unsuitable parish priest ${ }^{64}$, initiate inquests

59 The Mesa do Despacho (Ecclesiastical Chamber) had to meet frequently, especially on the eve of hearings, and the feitos (procedural steps) could only be dispatched in the presence of the provisor, vicar general and judges. See, for example Regimento dos officiaes..., cit., fol. 10v-14v; $18 \mathrm{v}-19$.

${ }^{60}$ See J. R. GouveIA, A Quarta Porta do Inferno..., cit., 174-185; P. G. Muniz, O tribunal episcopal..., cit. For requests for commutation of fines see, for example, Arquivo da Universidade de Coimbra [from now on AUC], Caixas da Câmara Eclesiástica, III-D, 1º , 6, 2, 9-14, 17, doc. 15.

${ }^{61}$ See A. M. Hespanha, Poder e Instituições..., cit., 43-44; F. AlmeIDA, História da Igreja..., cit., 2 : 231-236; P. F. SANTOS, Carentes de justiça..., cit., 102-122.

${ }^{62}$ On matters of patronage see F. Bethencourt, $A$ Igreja, en F. Bethencourt - K. ChaudhuRI, História da Expansão Portuguesa, 5 vols., Temas e Debates, Lisboa 1988, 2: 369-386; J. P. PAIVA, Os Bispos de Portugal e do Império, Imprensa da Universidade de Coimbra, Coimbra 2006, 38 78, 171-288; J. P. PaIva, A Igreja e o Poder, en C. M. Azevedo, História Religiosa de Portugal, 3 vols., Círculo de Leitores, Lisboa 2000, 2: 138-143; N. da S. GonÇALVES, Padroado, en C. M. Azevedo, Dicionário de História Religiosa de Portugal, 4 vols., Círculo de Leitores e Centro de Estudos de História Religiosa, Lisboa 2001, 3: 364-368; P. Ganster, Churchmen, en L. S. HoBERMAN - S. M. SCOLOw, Cities and Society in Colonial Latin America, University of New Mexico Press, Albuquerque 1986, 137-163. For consultation of bulls that granted the right of royal patronage over the overseas territories see: Corpo Diplomático Portuguez, Typographia da Academia Real das Sciencias, Lisboa 1865, 1: 254-257.

${ }^{63}$ See examples in: Arquivo Histórico Ultramarino [from now on AHU], ACL, CU, 009, cx. 26, doc. 2725; AHU, ACL, CU, 013, cx. 13, doc. 1199; AHU, ACL, CU, 013, cx. 14, doc. 1280.

${ }^{64}$ See AHU, ACL, CU, 015, cx. 17, doc. 1692. 
against priests for immoral behavior ${ }^{65}$, or even to review processes of Indian women against clerics ${ }^{66}$. Conflicts of jurisdiction in other judicial instances also helped limit the sphere of action of the diocesan Ecclesiastical Justice ${ }^{67}$. That situation led some authors to argue, with obvious exaggeration, that the ecclesiastical administration was a sort of department of the State, leaving the bishops immobilized and inoperative ${ }^{68}$. Obviously, the ecclesiastical structures were subordinated to imperial interests, but this does not mean that their activity was any different in the metropole and other Portuguese colonies $^{69}$.

The episcopal administration, headed by the bishop, provisor and vicar general, all of whom were assisted by a number of judicial officers, was structured around two organisms that worked in a cooperative and complementary way $^{70}$. On one side, there was the Ecclesiastical Chamber or Mesa do Despacho where matters of spiritual nature were dealt with. On the other, the Episcopal Court was the tribunal that judged crimes that came under ecclesiastical jurisdiction ${ }^{71}$. Only the provisor, with the corresponding registrar and judges, had entry to Mesa do Despacho. The vicar general, delegated by the bishop, normally presided over the sessions in the Auditorio, but the provisor could also oversee judicial causes that were related to his jurisdiction, that is, those of spiritual nature ${ }^{72}$. Thus the need for the Regimento do Auditório to register

${ }^{65}$ See AHU, ACL, CU, 015, cx. 109, doc. 8452.

${ }^{66}$ See AHU, ACL, CU, 013, cx. 37, doc. 3500.

${ }^{67}$ See AHU, ACL, CU, 015, cx. 219, doc. 14833; AHU, ACL, CU, 015, cx. 129, doc. 9775; AHU, ACL, CU, 015, cx. 195, doc. 13411.

${ }^{68}$ See S. B. Holanda (ed.), História Geral da Civilização Brasileira, 11 vols., Difusão Europeia do Livro, S. Paulo 1960, 2: 51-75; E. HoornaerT et al., História da Igreja..., cit., 180, 280; R. REnOU, A cultura explícita, en J. Serrão - A. H. O. Marques, Nova História da Expansão Portuguesa, Editorial Estampa, Lisboa 1992, 7: 373.

69 See J. P. PaIVA, Os bispos..., cit., 182-213; J. P. PAIVA, Os bispos do Brasil e a formação da sociedade colonial (1551-1706), Textos de História, revista da pós-graduação em História da UnB 14-1/2 (2006) 11-34; J. P. PAIVA, A Igreja e o Poder..., cit., 135-139. I personally substantiated this in comparative studies on vigilance and disciplining of clerical lasciviousness in the metropolis and the Brazillian colony, see J. R. GouvEIA, A Quarta Porta do Inferno..., cit.

${ }^{70}$ See J. P. PaIVa, Dioceses..., cit., 187-199.

${ }^{71}$ See J. P. PAIVA, $A$ administração diocesana ..., cit., 71-110. Patrícia Ferreira proposes a different terminology, arguing that the Ecclesiastical Justice was distributed into two forums: gracioso and contencioso (civil actions and crimes), although, like this author ends up admitting based on studies by Paolo Prodi, the word forum is very complex in legal and theological literature. See P. F. SANTOS, Carentes de justiça..., cit., 15, 125, 131.

${ }_{72}$ The vicar general could also superintend the Mesa do Despacho, but only when the provisor was absent. Regimento dos officiaes..., cit., fol. 4-5; 7v-9. 
the profiles and competences of the provisor and respective registrars of the Mesa do Despacho ${ }^{73}$.

The different activities of judicial bureaucracy took place in several physical spaces. First and foremost was the Episcopal Palace, official residence of the bishop. Then there was the Episcopal Court, which had its own building with a chamber of audiences and other quarters for the agents of the Tribunal. Both the provisor and the general vicar worked in their residences with the corresponding registrars, as did the judges of the Mesa do Despacho, who dealt with matters related to episcopal justice in their homes. And finally there was a prison to hold defendants who were to appear in hearings or serve sentences ${ }^{74}$.

However, there was actually great divergence among the different dioceses regarding this matter. In some, the physical spaces of diocesan justice were separate, while in others they coexisted in the same building. In the Brazilian colony the situation was much more precarious than in the metropolis; some dioceses didn't even have an episcopal palace, and most had no prison $^{75}$.

\section{The Episcopal Court (Auditório) of the Diocese of Coimbra IN THE 16Th CENTURY: Profiles AND COMPETENCES OF Justice OfFicers}

The diocesan Ecclesiastical Justice was composed of several ministers who worked there daily, and received salaries that varied according to the nature and quantity of cases they dealt with. To qualify for the office they had to meet certain prerequisites relating to conduct, age, purity of blood and education. Some of these officers were awarded regular or occasional prerogati-

73 The registrars of the Mesa do Despacho were so closely associated to the bureaucracy of the Tribunal that the Coimbra's regiment ordered by D. Afonso de Castelo Branco stipulated that no individual be freed without his release being registered by the registrars of the chamber, auditório and visitation. Regimento dos officiaes..., cit., fol. $10 \mathrm{v}-14 \mathrm{v} ; 19$.

${ }^{74}$ Two documentary examples of these private physical spaces where diocesan judicial matters were dealt with can be found in AUC, Devassas da cidade de Coimbra, Liv. 32 (1709); AUC, Caixas da Câmara Eclesiástica, III D, 1º 6, 2, 8, doc. 9, fol. 2.

75 See Belém, Arquivo da Cúria Metropolitana de Belém, Livro de provisões, 1722-1821, fol. 2, 11; 20; Rio de Janeiro, Biblioteca Nacional do Rio de Janeiro, D9, 0, Cx. 0748, pac. 2, doc. 3, m0001; Rio de Janeiro, Arquivo da Cúria do Rio de Janeiro, Livro de denúncias e querelas contra padres, 1794-1818, fol. 151-162. 
ves and distinctions that were similar to those granted to secular justices ${ }^{76}$. The most eminent offices were generally filled by individuals who were of the confidence of the bishop or whoever governed the diocese when the See was vacant ${ }^{77}$.

The functions and profiles of these officers, defined on regiments, were so specialized that their responsibilities can be easily categorized. The first regiment of the Coimbra Episcopal Court was ordered in 1547 by the bishop D. João Soares. In 1591 the bishop D. Afonso de Castelo Branco ordered a new regiment, published in 1592, incorporated in the Constituições Sinodais, and reprinted again in 1728. I have divided the officers into various informal sections in the following scheme to better comprehend the organization of Coimbra's Episcopal Court in the 16th century.

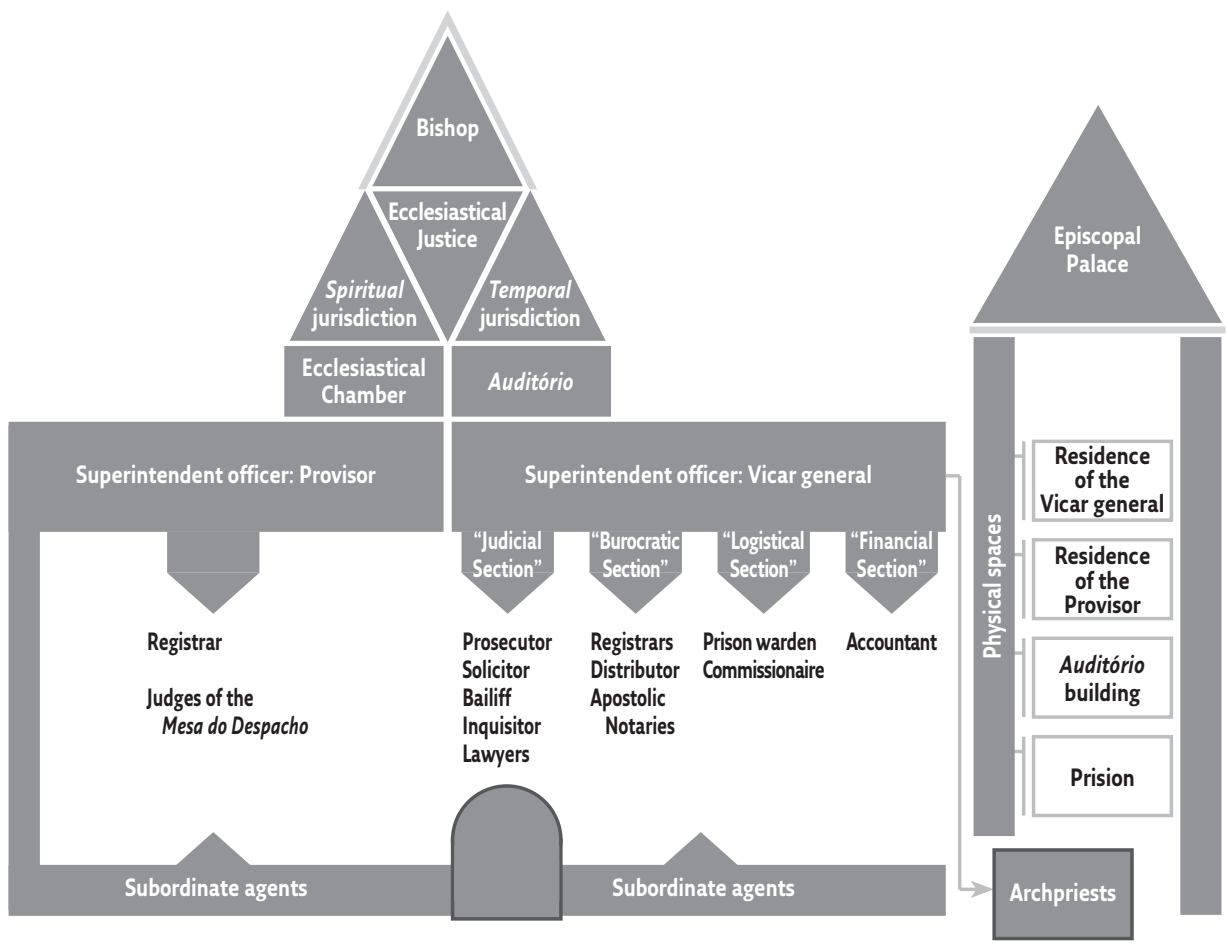

Fig. 1. Structure of Coimbra's diocesan judicial system in the 16th century.

\footnotetext{
${ }^{76}$ See F. AlmeIDA História da Igreja..., cit., 2: 231-236.

77 See J. P. Parva, Dioceses..., cit., 187-199.
} 
Surveys of sources produced by Auditório of Coimbra allow us to conclude that this structure continued in existence until at least the mid-18th century. The number of officials in each section varied by dioceses, as well as according to the different chronological periods. The profiles and competences of each of these officers will be analyzed below.

\subsection{Presiding Fudge of the Ecclesiastical fustice: The Bishop}

Apart from having to choose, nominate and discipline the officers who worked in the Ecclesiastical Justice, as presiding judges they also had a number of other competences in the judicial administration of the diocese. These included: commutation of final rulings and waivers of temporary sentences, visits of the Cathedral Chapter - in spiritual and temporal matters, establishing residences for the justice officers, allocating places of exile, ordering the application of apostolic decrees on any kind of benefits, imposing holy days and fasting days, knowledge of pardons regarding remission of a crime or respective sentences. The antiste delegated important functions to the provisor and vicar general ${ }^{78}$.

\subsection{The Ecclesiastical Chamber/Episcopal Directorate (Mesa do Despacho)}

The nomination of the agents who worked in the Ecclesiastical Chamber, with the exception of the judges, and the discrimination of their functions in the Regimento dos oficiais do Auditório (Regiment of the officers of the Auditório), shows that the Ecclesiastical Chamber and the Episcopal Court (Auditório) had different but complimentary, judicial roles ${ }^{79}$.

\subsubsection{Superintendent Officer: Provisor}

The office of provisor was designed for the spiritual administration of souls and the ministry of sacraments. The individual who took this post had to be a priest, mature in age, «serious», an experienced scholar, and not obstinate $^{80}$. His judicial responsibilities included taking the visitation books to the

\footnotetext{
${ }^{78}$ See Regimento dos officiaes..., cit., fol. 1-2v, 6-7v, 10v-14; J. P. PAIVA, A administração diocesana..., cit., 71-110.

79 See Regimento dos officiaes..., cit., fol. 10v-14v; 19.

${ }^{80}$ See Regimento dos officiaes..., cit., fol. $2 \mathrm{v}-4$.
} 
Mesa do Despacho to follow up on the offenses that were within his jurisdiction, issue licenses of absolution for those who had deceased in excommunication but had (previously) shown signs of contrition, issue letters to participants against unruly people who didn't confess within the obligatory period ${ }^{81}$. Marriage impediments announced in churches were brought to him, or submitted to the Mesa do Despacho for appraisal. He was also entrusted with asking the customary matrimonial questions before a trial became litigious. In the event that the parties agreed to marry he could acquiesce, but if there was disagreement, it was up to the vicar general to decide on the case ${ }^{82}$.

\subsubsection{Subordinate Officer: Registrar}

The registrar of the Ecclesiastical Chamber prepared the written records of the most important matters of the bishopric, which he kept in a special coffer in the Cabido (Chapter of the See). He was required to be fair, honest, prudent, and discrete. He was responsible for keeping a book to record and transcribe all the letters of «confirmação de benefícios» (confirmation of parochial benefits) ${ }^{83}$. Each page was signed and numbered by the provisor or vicar general.

He was prohibited, under penalty of suspension and payment of fines, to issue certificates of autos (edicts) to any individual, unless the parties had requested it and the judges had previously given their formal consent ${ }^{84}$. Neither the registrars of the Ecclesiastical Chamber nor of the Episcopal Court could get involved in each other's business ${ }^{85}$.

\subsection{The Episcopal Court (Auditório)}

\subsubsection{Superintendent Officer: Vicar General}

Only individuals who were ordained and over thirty years of age could occupy the position of vicar general. To be eligible they were required to be doctors, graduated in cannon law, or be sufficiently scholarly. They had to show rectitude in their conduct, benignity, meekness and benevolence. Like

\footnotetext{
81 See Regimento dos officiaes..., cit., fol. $2 \mathrm{v}-4$.

82 See Regimento dos officiaes..., cit., fol. $2 \mathrm{v}-4$.

83 See Regimento dos officiaes..., cit., fol. $17 \mathrm{v}-22 \mathrm{v}$.

84 See Regimento dos officiaes..., cit., fol. $17 \mathrm{v}-22 \mathrm{v}$.

85 See Regimento dos officiaes..., cit., fol. $17 \mathrm{v}-22 \mathrm{v}$.
} 
the provisor, this person had to be accommodating to all those involved in the Auditório ${ }^{86}$.

The vicar general was responsible for presiding over court hearings that involved disputes and accusations of offenses that pertained to the ecclesiastical forum. He was required to publish the processes or «feitos» that he had dealt with so that the lawyers could emit their opinions; make the summaries and have defendants arrested or released; investigate offenses that came under the Tribunal's jurisdiction; take care of testaments, execute the pious wills of the deceased and write out a «quitação em forma» (settlement) after certifying that these had been fulfilled and signing the list of witnesses ${ }^{87}$.

It was also the duty of the vicar general to be informed of all the crimes and accusations registered in visitations, if reduced to the litigious forum, to question witnesses in cases of serious crimes, and to perform all the tasks that pertained to the office of provisor if the later were absent or inexistent, as was often the case in the Brazilian dioceses. It was his duty to impose penalties on officials who didn't turn up at the court hearings of people held in prison. Finally, he had to sign the sentences once the registrar had given proof that all the officers had been remunerated ${ }^{88}$.

\subsubsection{Subordinate Officers}

\subsubsection{Fudicial Section}

\section{A) Prosecutor}

The prosecutor was the officer in charge of legally requesting with diligence all causes pertaining to episcopal jurisdiction. He was required to hold a degree in Canon Law or Civil Law, oversaw all crimes that qualified to be judged in the Tribunal, and initiated the court procedures. He also had the responsibility of ensuring procedural secrecy ${ }^{89}$.

The vote and opinion of the prosecutor took precedence over lawyers in court proceedings. He had to present the «feitos da justiça» (procedural steps) in court hearings as well as the lists of prisoners and individuals held in cus-

\footnotetext{
86 See Regimento dos officiaes..., cit., fol. 4-5.

87 See Regimento dos officiaes..., cit., fol. 4-5; 7v-9.

88 See Regimento dos officiaes..., cit., fol. 4-5; 7v-9; 16v-17v.

89 See Regimento dos officiaes..., cit., fol. 15-16v.
} 
tody (seguros), and emit his opinion about all those whose defense he was in charge of. He was to follow up on «autos de querela» (disputes) and inquests even if the plaintiffs had withdrawn their accusations, unless the vicar general closed the case. It was his job to issue indictments (libelos da justiça) after notifying (correr folba) all the registrars of the Auditório, the Chamber and the visitation. He also had to issue edicts against defendants who had been charged in the interrogations of pastoral visits once they were formally indicted by the Mesa do Despacho. He then had to proceed with the interrogation of the relevant witnesses. Little is known about his salary except that he was paid the same amount as the prosecutors and that it was stipulated by the crown tribunals ${ }^{90}$.

\section{B) Solicitor}

The solicitor was responsible for safeguarding the correct administration of episcopal justice. He had a list of all the procedural steps (feitos da justiça) according to which he was supposed to officially summon all those guilty. It was up to him to be informed of all crimes committed in the diocese, and provide true and correct information to the prosecutor ${ }^{91}$.

It fell to him to solicit interrogations and to accompany the inquisitor and registrars. Finally, he was to encourage the brief and efficient dispatch of these processes. If he was accountable for any delays, he would not receive the proceeds due, and would have to pay both deferment costs and a fine, to cover justice expenses. In the case of a relapse the penalty was bigger and could lead to suspension. Apart from receiving the salary stipulated for solicitors of secular justice, solicitors of the Auditório received a fourth of all justice feitos $d a$ justiça (court procedures) that they solicited ${ }^{92}$.

\section{C) Bailiff}

The bailiff was the officer in charge of holding defendants in the episcopal prison and denouncing public crimes. He was required to be fair, prudent and impartial, and was obliged to present arrest and search warrants, except in

\footnotetext{
90 See Regimento dos officiaes..., cit., fol. 15-16v.

${ }^{91}$ See Regimento dos officiaes..., cit., fol. 26v-27.

92 See Regimento dos officiaes..., cit., fol. 26v-27.
} 
situations of flagrante delicto. If he made an arrest that went against the terms of the Regimento, he would be provisionally suspended. In case of negligence he would be convicted and substituted by the prosecutor ${ }^{93}$.

He was forbidden to discuss his fees with the parties before a sentence was not issued, nor could he accept donations or sleep in the house of individuals confronted with the law. Whenever the bailiff presented charges the prosecutor had to serve as prosecutor. He received an allowance of one tostão (testoon) for each detention he made in Coimbra. If he made an arrest outside of the city, his fee increased by one tostão for every league traveled by foot. He was paid by the party involved in the process, by the actual prisoner, or by the expenses of justice. If he charged more than he was due, he had to refund the double of that amount and was suspended for one year ${ }^{94}$.

\section{D) Inquisitor}

The inquisitor was the officer in charge of carrying out interrogations related to causes pending in the Episcopal Court. In the absence of an inquisitor or if there was some impediment, a commissioner would be nominated. With time this practice became the norm, the position of inquisitor ceased to exist, and priests were paid a commission to carry out this task ${ }^{95}$.

For each cause the inquisitor had to interrogate up to twenty witnesses. If he interrogated others, the depositions would not have effect, and neither he nor the registrar would receive a salary. As a representative of justice he could only interrogate witnesses who had been registered, under punishment of paying a thousand réis ${ }^{96}$.

Interrogations were initiated with cross-examinations of the witnesses of the «author» (plaintiff), and only after that those of the defendant. Regarding cases of marital and «beneficial» crime (irregularities in naming priests) in which the «quality» of the witnesses justified it, the inquisitor could never initiate an interrogation without first informing the vicar general. If he failed to proceed in this way, he would be obliged to pay four hundred réis, the court

\footnotetext{
93 See Regimento dos officiaes..., cit., fol. $22 \mathrm{v}-24 \mathrm{v}$.

${ }_{95}$ See Regimento dos officiaes..., cit., fol. $22 \mathrm{v}-24 \mathrm{v}$.

95 See AUC, Caixas da Câmara Eclesiástica, III, D, 1, 6, 2, 25, doc. 20. See also AUC, Caixas da Câmara Eclesiástica, III, D, 1, 6, 2, 27, doc. 4; Lisboa, Arquivo Nacional da Torre do Tombo [from now on ANTT], Inquisição de Coimbra, processo $\mathrm{n}^{\circ} 19$.

96 See Regimento dos officiaes..., cit., fol. $24 \mathrm{v}-25 \mathrm{v}$.
} 
sessions would be declared null and void, and other penalties indicated in the Royal Regimento would be applied ${ }^{97}$.

Failure to fulfill the duties of his office without presenting a valid justification resulted in a six month suspension. It was then up to the vicar general to provide a substitute ${ }^{98}$.

\section{E) Lawwers of Defence/Prosecution (Procuradores)}

The procuradores were laymen licensed in Law, and did not work exclusively for the Auditório. To exercise their office they needed authorization from the bishop, and the validity of was up to the discretion of the prelate ${ }^{99}$.

Their role was to prepare trials, and to defend and prosecute. They legally represented the parties, whether they were present or absent or unable to appear in the Tribunal hearings. They could not, however, represent individuals that were absent from the Kingdom without previously paying a bond. They were responsible for issuing suspicions against justice officers who inhibited indictments ${ }^{100}$.

They were required to be diligent and avoid delays; otherwise they had to pay one tostão per each day of deferment. They were not allowed to exercise power of attorney until they had paid the debt ${ }^{101}$. In cases of mixed justice, the procuradores who bypassed episcopal justice in favour of royal justice were suspended and only readmitted by decision of the bishop ${ }^{102}$. Their salaries were calculated according to the Regimento of the courts of the crown. All that is known is that for each of the more serious criminal cases, the procuradores would receive nine hundred réis ${ }^{103}$.

\subsubsection{Bureaucratic Section}

\section{A) Registrars}

The number of registrars that worked in the episcopal Tribunal varied according to the number of procedural causes in each one. Registrars working

\footnotetext{
97 See Regimento dos officiaes..., cit., fol. $24 \mathrm{v}-25 \mathrm{v}$.

98 See Regimento dos officiaes..., cit., fol. $24 \mathrm{v}-25 \mathrm{v}$.

99 See Regimento dos officiaes..., cit., fol. 5; 16v-21.

100 See Regimento dos officiaes..., cit., fol. 6-7v, 10v-14.

101 See Regimento dos officiaes..., cit., fol. 6-7v, 10v-14.

102 See Regimento dos officiaes..., cit., fol. 6-7v, 10v-14.

103 See Regimento dos officiaes..., cit., fol. 6-7v, 10v-14.
} 
under the vicar general did so on a rotating basis and according to seniority; in Coimbra their term lasted one month. The main task of the registrars who assisted the vicar general was to write the minutes of the court proceedings that took place daily in the Episcopal Court, and record trials, hearings and rulings. The other registrars only carried out distribution orders ${ }^{104}$.

The activity of the registrars was revised yearly by the vicar general. They were prohibited, unless expressly authorized by the judge, to work from home. They were assigned the task of accompanying the inquisitor and recording all depositions made by the witnesses listed in a roster signed by the vicar general ${ }^{105}$.

Registrars had to deliver the written drafts solely to the vicar general and procuradores within a stipulated deadline, which if not met would incur a penalty. It was also their duty to give previous notification to all parties, independently of whether the trials were in the city or elsewhere, under penalty of a fine of four hundred réis ${ }^{106}$.

Like all other officers, they could not redirect a lawsuit to a secular judge without the consent of the bishop or the vicar general, under penalty of suspension and a fine of two thousand réis. Nor could they adjourn a trial, under penalty of paying the costs of deferment and four hundred réis. For the sake of equity, registrars could not take on a case without it first being duely allocated to them. Infringement resulted in a six month suspension, without remission. If they repeated the offense, they were suspended for a year and were obliged to pay a fine of ten cruzados. If they recidivated, they would be banned ${ }^{107}$.

The salaries of the registrars varied. If they had to travel to record the depositions of someone who had requested the Tribunal to initiate court proceedings, the plaintiffs paid them an amount stipulated by the vicar general at the end of the interrogation. If, on the other hand, the party interested in the carrying out enquiries was the Tribunal, the registrars would pay the expenses and submit them to the Auditorio, where all their costs would be added up. These were presented to the sentenced party who was then obliged to reimburse the registrars ${ }^{108}$.

\footnotetext{
${ }^{104}$ See AUC, Caixas da Câmara Eclesiástica, III D, 1º, 6, 2, 8, doc. 9, fol. 2.

105 See Regimento dos officiaes..., cit., fol. 7v-9; $18-22 \mathrm{v}$.

106 See Regimento dos officiaes..., cit., fol. 7v-9; 18-22v.

107 See Regimento dos officiaes..., cit., fol. 7v-9; 18-22v. In the Brazilian bishoprics the work of the registrars' was also controlled, see C. BosCHI, As Visitas Diocesanas e a Inquisição na Colónia, en Actas do $1^{\circ}$ Congresso Luso-Brasileiro sobre Inquisição, 3 vols., Sociedade Portuguesa de Estudos do século XVIII, Universitária Editora, Lisboa 1989, 2: 965-996.

108 See Regimento dos officiaes..., cit., fol. 7v-9; 18-22v.
} 


\section{B) Apostolic Notaries}

The apostolic notaries did not work exclusively for the episcopal tribunal. Their role was to write notifications and certifications of the legal proceedings. They were nominated by the prelates through a delegation of the papal jurisdiction ${ }^{109}$. The rescript of Julius II Ex querela carissimi of 28 June 1505 directed to the archbishops and bishops of Portugal, ordered an examination of the notaries of the respective dioceses and those found not competent to be divested of their office ${ }^{110}$.

\section{C) Distributor}

The distributor was responsible for the distribution of the bureaucratic work of the Auditorio. He distributed all the ordinary court procedures of the episcopal tribunal. He also had to deliver indictments, embargos and autos dos processos to the vicar general. He was required to distribute the work fairly among the registrars ${ }^{111}$.

He was obliged to record the distribution of all work in a bound book, in clear handwriting and without smudges, which was to be kept in strict confidence under penalty of excommunication and payment of a fine which would increase in case of reoccurrence. The distributor was supervised by the vicar general, who analyzed the distribution book every trimester and heard the registrars on this subject. The book was to be kept for thirty years and only during the first five years was it available for consultation. In the absence of a distributor this work was done by a registrar ${ }^{112}$.

\section{D) Letter Carrier (Corredor de folhas)}

Although this office is not mentioned in the Regimento of 1592 it appears in later documents, namely in general inquests, and was probably created as a result of the bureaucratic growth in the Episcopal Court. Letter carriers dispatched documents between the various officials of the Tribunal ${ }^{113}$.

\footnotetext{
See Regimento dos officiaes..., cit., fol. 7v-9; 18-22v.

110 See F. AlmeIDA, História da Igreja..., cit., 2: 231-236.

111 See Regimento dos officiaes..., cit., fol. 25v-26.

112 See Regimento dos officiaes..., cit., fol. $25 \mathrm{v}-26$.

113 See AUC, Caixas da Câmara Eclesiástica, Devassa geral para se saber do procedimento dos reverendos ministros da Mesa da Justiça Eclesiástica e dos mais oficiais da justiça (general inquests to learn about the procedures of the reverend ministers of the Mesa of the Ecclesiastical Justice and other officers of justice) III D, $1^{\circ}, 6,2,19,5$.
} 


\subsubsection{Logistical Section}

\section{A) Prison warden (Aljubeiro)}

The prison warden kept the keys of the prison, and was in charge of overseeing its maintenance and watching over the prisoners. Before releasing inmates he had to make sure that these had served their time, that a release order had been issued, and that the vicar general had signed the corresponding entry in the prison book. He could not allow: games and fights among inmates, prostitutes or concubines, swearing or blasphemy, any exchanges with their lovers, bribery, and he could not put prisoners to work ${ }^{114}$.

His salary was paid by the prisoners. Anyone who was incarcerated had to pay a fee (the amount is unknown), as well as the cost of incarceration to the prison warden ${ }^{115}$.

\section{B) Commissionaire (Porteiro)}

The Commissionaire took care of the court house of the Auditório. $\mathrm{He}$ was in charge of opening the doors and ringing the bell at set times. He had to clean the courtroom, and do all maintenance and necessary repairs. He was required to be honest, solicitous, and go regularly to the vicar general's house and be at his disposal ${ }^{116}$.

He was under the orders of the bailiff and the prosecutor, and he was responsible for summoning people to court and making announcements. He was paid in loco by the parties involved in each court hearing. If the author of the cause was the Tribunal, his work would be paid only at the end of the trial by the party that had been sentenced to pay the costs. The rest of his work was calculated by the accountant and paid for by the Tribunal ${ }^{117}$.

\subsubsection{Financial Section}

A) Accountant

The position of accountant was created to handle the accounting (revenue and expenses) of causes in the Episcopal Court, namely pecuniary penal-

\footnotetext{
114 See Regimento dos officiaes..., cit., fol. 27-27v.

115 See Regimento dos officiaes..., cit., fol. 27-27v.

116 See Regimento dos officiaes..., cit., fol. $27 \mathrm{v}-28$.

117 See Regimento dos officiaes..., cit., fol. $27 \mathrm{v}-28$.
} 
ties and the salaries of the officers of the Tribunal. This officer was required to be sensible and fair regarding the costs of court cases, and sometimes he had to define the amount that should be demanded of the parties involved. He abided by the rules of the Lei Geral do Reino (General Law of the Kingdom) which stipulated that each page should have 25 lines with 30 words each ${ }^{118}$. The financial movements he recorded show that the income of the Tribunal was generated by the fines and monetary penalties ${ }^{119}$.

\subsubsection{Officers of the sub-diocesan judicial administrative divisions: archpriests}

Portugal had a fairly uniform diocesan administrative model with a highly centralized organizational structure thanks to the small number of dioceses, and to a reduced and homogeneous territorial universe. However, to expedite the administration of justice and the control by the bishopric, particularly in the more remote, extensive and populous areas, in some dioceses there were archpriests, also called vicars forane, who had jurisdiction over all causes in which costs and fines involved small amounts of money ${ }^{120}$. The work of these officers was indispensable for the exercise of justice since they judged the minor causes, and through careful vigilance selected and forwarded those offenses which pertained to the jurisdiction of the Episcopal Court ${ }^{121}$. They were, therefore, sub-diocesan administrative and judicial units that carried out tasks assigned to them by the bishop ${ }^{122}$.

The archpriests of the bishopric of Coimbra had jurisdiction over all causes in which the payment of monetary penalties was less than five hundred réis (such as some verbal offenses). This did not include bens de raiz (property) and

118 See Regimento dos officiaes..., cit., fol. 26-26v.

119 See Regimento dos officiaes..., cit., fol. 16v-17v.

120 See A. C. Rodrigues, Clergy..., cit.

${ }^{121}$ In the immense and discontiguous territory of the Brazilian colony the vicar forane assumed a preponderant role. See A. C. Rodrigues, Clergy..., cit.; P. G. MunIZ, O tribunal episcopal..., cit., 6-7; M. C. PIRES, Fuizes..., cit., 117. Not only did vicars forane usually have other agents like registrars, bailiffs and treasurers, but they were often nominated for life. See Regimento do Auditorio Eclesiastico, in Primeiras Constituições..., cit., fol. 110; ANTT, Mesa da Consciência e Ordens, Padroados of Brasil, Maranhão, maç. 4, cx. 4, uncatalogued documents; Mariana, Ecclesiastical archives of Mariana, Books of the Ecclesiastical Justice, 1736-1747; 1740-1749; 1748-1765, file 6, second shelf.

122 See J. P. PAIva, Geografia Eclesiástica, en C. M. Azevedo (ed.), Dicionário de História Religiosa de Portugal, 4 vols., Círculo de Leitores e Centro de Estudos de História Religiosa, Lisboa 2000, 2: 294-306. 
disputes about tithes between churches. Their duties included taking action against clerics who had been caught in forbidden places, monitoring the collection of tithes, controlling decency in processions, advising the bishops when a position (beneficio) became vacant, making inventories of the estates of deceased parish priests, and detention for flagrante delicto. They were denied participation in beneficial, criminal, usurious and matrimonial causes ${ }^{123}$.

If they took it upon themselves to judge causes for which they did not have jurisdiction, their decision would be annulled and they would be fined one thousand réis to cover judicial expenses. In cases where they did have jurisdiction this officer could issue sentences and arrest offenders, as long as the parties did not appeal or the causes were aggravated ${ }^{124}$.

\section{CONCLUDING REMARKS}

The Ecclesiastical Justice was a bureaucratized and organized apparatus. The assignment of positions was a prerogative of the bishop, and the choice of individuals was made according to criteria which differed for each office, but which generally involved their suitability, age, education, and professional and ethno-religious status. It should be noted that the standards for an ideal profile in matters like age, education and psychological characteristics were only prerequisites for the higher offices of the Auditório. Although there is no doubt that some of the subordinate agents did not work exclusively for the Tribunal, existing documentation regarding salaries does not prove that all the officers were remunerated.

Externally the Ecclesiastical Justice exercised a vast activity of vigilance and disciplining of the ideas and behavior of Christianity, in an effort to maintain order. On the other hand, internally it was preoccupied with checking the performance of the numerous judicial agents in this hierarchical organization. The bishop occupied the top of the Ecclesiastical Justice and had a series of competences that were his exclusive múnus, especially regarding questions closer to the diocese. He delegated a considerable part of his judicial duties to the provisor, who superintended the Ecclesiastical Chamber, and to the vicar general who managed the Auditório. Subordinate officials with specialized, well-defined functions worked in each administrative section, and were only

123 See Regimento dos officiaes..., cit., fol. 28-28v.

124 See Regimento dos officiaes..., cit., fol. 28-28v. 
substituted by another agent in the impossibility or absence of its officeholder. Analysis revealed that the activity of this organism of justice extended to several fields which can be grouped into four main sections: judicial, bureaucratic, logistical and financial.

The diocesan judicial mechanism had been undergoing a restructuring process since the dawn of the modern period. It became quite complex in the post-Trent period with the intensification and expansion of its judicial action on the ideas and behavior of the whole of Christianity. At the same time it was strongly committed to supervision and internal control. Oriented to the full implementation of justice, the Regimento was not merely an instruction manual that determined what procedures were to be adopted in each «cause», and the competences and duties of the justice agents. It was also a normative judicial code aimed to maintain internal discipline in the Ecclesiastical Justice system, stipulating sentences to be applied to offenders. Three lapses were allowed, each with a penalty or suspension of functions, differentiated according to the defendant and frequency of recurrence.

Having examined the organizational structure of the Ecclesiastical Justice, the profiles required of it agents, the competences necessary for exercising each office, and the penalties stipulated for offenders, the next step is to study the individuals named for these offices and examine their performance in carrying out their respective duties. It will be essential, along with the analysis of external matters of the Ecclesiastical Justice, to focus on intermediary spheres of justice like matters of conscience (foro da consciência) in certain cases of exoneration. It is possible that this may be impaired by a shortage of documentation, but it is the only path to take if we wish to strengthen our understanding of those important ecclesiastical judicial centers of the modern world. 


\section{Bibliography}

AlmeIDA, F., História da Igreja em Portugal, Portucalense Editora-Livraria Civilização Editora, Porto 1968-1971, 5 vols.

Benedict, P., What is Post-Confessional Reformation History, Archive for Reformation History 97 (2006) 277-283.

Benedicto XVI, Confessionalization in France? Critical reflections and new evidence, en A. R. Mentzer - A. Spicer (eds.), Society and Culture in the Hugenot World, 1559-1685, Cambridge University Press, Cambridge 2001, 44-61.

Bethencourt, F., A Igreja, en F. Bethencourt - K. Chaudhuri, História da Expansão Portuguesa, 5 vols., Temas e Debates, Lisboa 1988, 2: 369-386.

Bianchi, H. - SimOndi, M. - TaYlor, I. (eds.), Deviance and control in Europe: papers from the European Group for the Study of deviance and Social Control, John Wiley and Sons, London 1975, 209 pp.

BonaCCHI, G., Legge e peccato. Anime, corpi, giustizia alla corte dei papi, Laterza, Roma-Bari 1995, 250 pp.

Boschi, C., As Visitas Diocesanas e a Inquisição na Colónia, en Actas do $1^{\circ}$ Congresso Luso-Brasileiro sobre Inquisição, 3 vols., Sociedade Portuguesa de Estudos do século XVIII, Universitária Editora, Lisboa 1989, 2: 965-996.

Britto, M. C., A atuação do Tribunal Episcopal do bispado de S. Paulo. Delitos e Fustiça Eclesiástica na Colonia (1747-1822), en Anais Eletrónicos do XXVIII Simpósio Nacional de História, Lugares dos historiadores: velhos e novos desafios, ANPUH, Florianopolis 2015, 1-12.

Cabral, A. V., Pratica judicial muyto util e necessaria para os que principiam os officios de julgar, e advogar, e para os que solicitão causas nos auditorios de bum e outro foro tirada de varios autores practicos e dos estylos mais praticados nos auditórios, Officina de Carlos Esteves Mariz, Lisboa Ocidental 1740, 396 pp.

Caminha, G. M., Tratado da Forma dos Libellos, Oficina dos Irmãos e Sobrinho Ginioux, Coimbra 1764, 216 pp.

Candau Chacón, M. L., Delito sexual y justicia eclesiástica en los Tiempos Modernos, en J. I. ForTEA - J. E. GELABERT - T. A. MANTECón (eds.), Furor et rabies. Violencia, conflicto y marginalización en la Edad Moderna, Servicio de Publicaciones de la Universidad de Cantabria, Santander 2004, 410-411.

—, Los delitos y las penas en el mundo eclesiástico sevillano del XVIII, Diputación Provincial, Sevilla 1993, 387 pp.

CAPEla, J. V., O Auditório Eclesiástico Bracarense e o fim da sua jurisdição temporal. O papel do arcebispo D. Frei Caetano Brandão, Bracara Augusta 108-121 (2005) 13-21. 
Carvalho, J., A jurisdição episcopal sobre leigos em matéria de pecados públicos: as visitas pastorais e o comportamento moral das populações portuguesas de Antigo Regime, Revista Portuguesa de História XXIV (1988) 121-163.

—, As visitas pastorais e a sociedade de Antigo Regime. Notas para o estudo de um mecanismo de normalização social, Coimbra 1985, 210 pp.

-, Comportamentos morais e estruturas sociais numa paróquia de Antigo Regime: Soure, 1680-1720: reconstituições, interpretações e metodologias, Faculdade de Letras, Coimbra 1997, 592 pp.

Corpo Diplomático Portuguez, Typographia da Academia Real das Sciencias, Lisboa 1865, 1: 254-257.

De Castro, G. P., Monomachia sobre as concórdias que fizeram os reis com os prelados de Portugal nas dúvidas da jursidição eclesiástica e temporal, José Francisco Mendes, Lisboa 1738, 266 pp.

De las Heras Santos, J. L., La criminalidad femenina ante la justicia episcopal en la Salamanca del siglo XVII, en I. M. R. D. BRAGA - M. T. HeRnÁNDEZ (eds.), As mulheres perante os tribunais do Antigo Regime na Peninsula Ibérica, Imprensa da Universidade de Coimbra, Coimbra 2015, 85-109.

Delumeau, J., Le Catholicisme entre Luther et Voltaire, Presses Universitaires de France, Paris 1979, 358 pp.

Enciclopedia Cattolica, Casa Editrice G. C. Sansoni, Firenze 1954, 12: 495-510.

Enciclopedia de la Religión Católica, Dalmau y Jover, S. A., Barcelona 1956, 7: 352.

FARR, J. R., Confessionalization and Social Discipline in France, 1530-1685, ARG 94 (2003) 276-293.

FeItler, B., Nas malhas da consciência. Igreja e Inquisiçãa no Brasil. Nordeste, 1640-1750, Alameda, Poebus, S. Paulo 2007, 291 pp.

FERRANTE, L., La sessualità come risorsa. Donne davanti al foro arcivescovile di Bologna (séc. XVII), Mélanges de l'École française de Rome 99-2 (1987) 989-1016.

—, «"Malmaritate" fra assistenza e punizione (Bologna sec. XVI-XVII)», en Forme e soggetti dell'intervento assistenziale in una città di antico regime, Il Mulino, Bologna 1986, 65-109.

Ganster, P., Churchmen, en L. S. Hoberman - S. M. Scolow, Cities and Society in Colonial Latin America, University of New Mexico Press, Albuquerque 1986, 137-163.

Gonçalves, N. da S., Padroado, en C. M. Azevedo, Dicionário de História Religiosa de Portugal, 4 vols., Círculo de Leitores e Centro de Estudos de História Religiosa, Lisboa 2001, 3: 364-368. 
GouveIA, J. R., A Quarta Porta do Inferno. A vigilância e disciplinamento da luxúria clerical no espaço luso-americano, 1640-1750, Chiado Editora, Lisboa 2015, $601 \mathrm{pp}$.

—, Os ladrões das honras e a repressão das desonras. A ação do fuízo Eclesiástico no Atlântico português (1640-1750), Revista Ultramares 4-1 (2013) 45-71.

—, Quod non est in actis, non est in mundo: mecanismos de disciplina interna e externa no Auditório Eclesiástico de Coimbra, Revista do Centro de História da Sociedade e da Cultura 9 (2009) 179-204.

Headley, J. - Hillerbrand, J. - Papalas, A. J. (eds.), Confessionalization in Europe, 1555-1700. Essays in honour and memory of Bodo Nischam, Ashgate, Burlington 2004, 17-25.

Hendrix, S., Post-Confessional Research and Confessional Commitement, Archive for Reformation History 97 (2006) 284-287.

Hespanha, A. M., Poder e Instituições no Antigo Regime, Edições Cosmos, Lisboa 1992, 128 pp.

Holanda, S. B. (ed.), História Geral da Civilização Brasileira, 11 vols., Difusão Europeia do Livro, S. Paulo 1960.

Hoornaert, E., A Igreja no Brasil - colónia, 1550-1800, 3th ed., Editora Brasiliense, S. Paulo 1994 (first edition was published in 1982), $92 \mathrm{pp}$.

Hoornaert, E. - Azzi, R. - Grijp, K. V. D. - Brod, B., História da Igreja no Brasil, Editora Vozes, Petrópolis 1977, 442 pp.

KrINSKi, M. L. (ed.), Promessas desfeitas: documentação paranaense em processos do Juizo Eclesiástico da Diocese de São Paulo, 1750-1796, Aos Quatro Ventos, Curitiba 2003, 135 pp.

Lacombe, J., A Igreja no Brasil Colonial, en S. B. Holanda (ed.), História Geral da Civilização Brasileira, 11 vols., Difel, S. Paulo 1977.

LEAL, B., La crosse et le batôn, Gulbenkian, Paris 2004, 595 pp.

LUís, M. A. F., Visitas Pastorais ao concelho da Lourinhã no século XVII, Lusitania Sacra 23 (2011) 169-187.

Marcocci, G. - Paiva, J. P. (eds.), História da Inquisição Portuguesa, 15361821, Esfera dos Livros, Lisboa 2013, 607 pp.

MARTINS, W. S., Contas testamentárias: a justiça eclesiástica e a execução de testamentos no Rio de faneiro (c. 1720-1808), en R. GUEDES - C. RODRIGUES - M. WANDERLEY (eds.), Últimas vontades. Testamento, sociedade e cultura na América Ibérica (séculos XVII e XVIII), Mauad Editora, Rio de Janeiro 2015, 408 pp.

Mattos, Y. - Muniz, P. G. (eds.), Inquisição e fustiça Eclesiástica, Paco Editorial, S. Paulo 2013, 364 pp. 
—, Vigiar a ortodoxia: limites e complementaridades entre a fustiça Eclesiástica e a Inquisição na América Portuguesa, Revista de História 171-2 (2014) 287-316.

Muniz, P. G., O tribunal episcopal do bispado do Maranhão: dinâmica processual e jurisdição eclesiástica no século XVIII, en B. FEITLER - E. S. SOUZA (eds.), A Igreja no Brasil. Normas e práticas durante a vigência das Constituições primeiras do Arcebispado da Baía, UNIFESP, S. Paulo 2011, 481-506.

—, Ordens religiosas e transgressão no Maranhão colonial, Tempo 16-32 (2012) 115-136.

—, Os processos da Igreja: documentos do Tribunal Episcopal enquanto fonte histórica, Fontes 1-2 (2014) 15-27.

—, Parochos imperfeitos: Fustiça Eclesiástica e desvios do clero no Maranhão colonial, PhD. diss., Federal Fluminense University, 2011, 341 pp.

MuÑoz, I. P., Pecar, delinquir y castigar: el Tribunal Eclesiástico de Coria en los siglos XVI y XVII, Institución Cultural «El brocence», Diputación Provincial de Cáceres, Salamanca 1992, 206 pp.

NunEs, J. R., Crime e castigo: pecados públicos e disciplinamento social na Diocese de Viseu (1684-1689), Revista de História da Sociedade e da Cultura 6 (2006) 177-213.

Oestreich, G., Neostoicism and the Early Modern State, Cambridge University Press, Cambridge 1982, 292 pp.

PaIVA, J. P., A administração diocesana e a presença da Igreja. O caso da diocese de Coimbra nos séculos XVII e XVIII, Lusitânia Sacra 2ª -3 (1991) 71-110.

-, A Igreja e o Poder, en C. M. AzEvedo, História Religiosa de Portugal, 3 vols., Círculo de Leitores, Lisboa 2000, 2: 138-143.

—, As estruturas do governo diocesano, en J. P. Parva (ed.), História da Diocese de Viseu, Diocese de Viseu e Imprensa da Universidade de Coimbra, vol. 2 (1505-1819), Viseu 2016, 206-224.

-, As visitas pastorais, en C. M. Azevedo (ed.), História Religiosa de Portugal, 3 vols., Círculo de Leitores, Lisboa 2000, 2: 250-255.

—, Baluartes da fé e da disciplina. O enlace entre a Inquisição e os bispos em Portugal, 1536-1750, Imprensa da Universidade de Coimbra, Coimbra 2011, 480 pp.

—, Dioceses e organização eclesiástica, en C. M. AzEvEdo (ed.), História Religiosa de Portugal, ed. Carlos Azevedo, 3 vols., Círculo de Leitores, Lisboa 2000, 2: 187-199.

—, El Estado en la Iglesia y la Iglesia en el Estado. Contaminaciones, dependencias y disidencia entre la monarquía y la Iglesia del reino de Portugal (1495-1640), Manuscrits 25 (2007) 45-57. 
—, Geografia Eclesiástica, en C. M. Azevedo (ed.), Dicionário de História Religiosa de Portugal, 4 vols., Círculo de Leitores e Centro de Estudos de História Religiosa, Lisboa 2000, 2: 294-306.

—, Inquisição e Visitas Pastorais. Dois mecanismos complementares de controlo social?, Revista de História e Teoria das Ideias 11 (1989) 85-102.

—, La réforme catholique au Portugal - les visites pastorales des évêques, Arquivos do Centro Cultural Calouste Gulbenkian XLIII (2002) 159-175.

-, Os Bispos de Portugal e do Império, Imprensa da Universidade de Coimbra, Coimbra 2006, 663 pp.

—, Os bispos do Brasil e a formação da sociedade colonial (1551-1706), Textos de História, revista da pós-graduação em História da UnB 14-1/2 (2006) 11-34.

-, The Portuguese secular clergy in the sixteenth century and seventeenth centuries, en E. ANDOR - I. G. TóTH (eds.), Frontiers of Faith. Religious Exchange and the Constitution of Religious Identities, 1400-1750, Central European University, European Science Foundation, Budapest 2001, 157-166.

—, Visitações, en C. M. Azevedo (ed.), Dicionário de História Religiosa de Portugal, Círculo de Leitores e Centro de Estudos de História Religiosa, Lisboa 2001, P-V-365-370.

Paiva, J. P. - Carvalho, J. R., A evolução das visitas pastorais da diocese de Coimbra nos séculos XVII e XVIII, Ler História 15 (1989) 29-41.

Palomo, F., A Contra-Reforma em Portugal, 1540-1700, Temas e Debates, Lisboa 2006, 130 pp.

—, La autoridad de los prelados tridentinos y la sociedad moderna. El gobierno de don Teotónio de Braganza en el arzobispado de Évora (1578-1602), Hispania Sacra 47 (1995) 587-624.

—, Una bibliografía imperfecta o el análisis fragmentario a treinta años de estudios sobre historia religiosa de la Península Ibérica en los siglos XVI-XVIII, Lusitania Sacra 21 (2009) 173-235.

Pires, M. C., Fuizes e Infratores. O Tribunal Eclesiástico do Bispado de Mariana, 1748-1800, ANNABLUME Editora, S. Paulo 2008, 134 pp.

Prodi, P., Disciplina dell' anima, disciplina del corpo e disciplina della società tra medioevo ed età moderna, Società editrice il Mulino, Bologna 1994, 972 pp.

Prosperi, A., Tribunali della conscienza. Inquisitori, confessori, missionari, Einaudi, Torino 1996, 708 pp.

Regimento do Auditorio Ecclesiastico do arcebispado da Babia, Metropoli do Brasil e da sua Relaçam e officiaes de justiça ecclesiastica e mais cousas que tocão ao bom governo do dito arcebispado, Officina de Pascoal da Silva, Lisboa Ocidental 1718. 
Regimento dos officiaes do Auditorio Ecclesiastico do bispado de Coimbra, Antonio de Mariz, impressor da Universidade, Coimbra 1592.

REINHARD, W., Disciplinamento sociale, confessionalizzazione, modernizzazione. Un discorso storiografico, en P. PRODI (ed.), Disciplina dell'anima, disciplina del corpo e disciplina della società tra medioevo ed età moderna, Società editrice il Mulino, Bologna 1994, 101-123.

—, Pressures towards Confessionalization? Prolegomena to a Theory of the Confessional Age, en S. Dixon (ed.), The German Reformation: The Essential Readings, Blackwell Publishing, Blackwell 1999, 169-192.

-, Reformation, counter-reformation, and the Early Modern State: a reassessment, The Catholic Historical Review 753 (1989) 383-404.

Renou, R., A cultura explícita, en J. Serrão - A. H. O. Marques, Nova História da Expansão Portuguesa, Editorial Estampa, Lisboa 1992, 7: 373.

Rodrigues, A. C., Clergy, Society and Power Relations in Colonial Brazil: on the Vicar Forane (vigário da vara), 1745-1800, E-journal of Portuguese History 13-1 (2015) 40-67.

—, Igreja e Inquisição no Brasil. Agentes, carreiras e mecanismos de promoção social - século XVIII, Alameda, S. Paulo 2014, 406 pp.

Roordenburg, H. - Spierenburg, P. (eds.), Social Control in Europe, 15001800, 2 vols., Ohio 2004.

Roper, L., Allegiance and Reformation History, Archive for Reformation History 97 (2006) 289-297.

RuBIO, R. S., Instituciones y poderes eclesiásticos en la Extremadura de finales del siglo XVIII, Norba 3 (1985) 113-125.

Rummel, E., The Confessionalization of Humanism in Reformation Germany, Oxford 2000, 224 pp.

Santos, F. F., Conflitos setecentistas: sociedade e clero nas vilas de Curitiba e Paranaguá, Master diss., Paraná University, 2008, 161 pp.

SANTOS, P. F., A justiça eclesiástica e os mecanismos de busca de infratores: as queixas, as querelas e as denúncias no século XVII, Boletim do Arquivo da Universidade de Coimbra 26 (2013) 137-160.

—, Carentes de justiça: juízes seculares e eclesiásticos na «confusão de latrocínios» em Minas Gerais, 1748-1793, PhD. diss., São Paulo University, 2013, 455 pp.

SCHILling, H., Religion, Political Culture and the Emergence of Early Modern State. Essays in German and Dutch History, E. J. Brill, Leiden 1992, 434 pp.

SeIdel, S. - Quaglioni, D. (eds.), I tribunali del matrimonio (secoli XV-XVIII), Il Mulino, Bologna 2006, 848 pp. 
Shagan, E. F., Can Historians End the Reformation?, Archive for Reformation History 97 (2006) 298-306.

SiLva, J. A., Tribunais Eclesiásticos, en C. M. AzEvedo (ed.), Dicionário de História Religiosa de Portugal, 4 vols., Círculo de Leitores e CEHR, Lisboa 2001, 4: 303-305.

SiLva, M. S., Dignidade e transgressão: mulheres no Tribunal Eclesiástico em Minas Gerais, 1748-1830, Editora da UNICAMP, Campinas 2001, 209 pp.

—, Normas e padrões do tribunal eclesiástico mineiro (1750-1830) e o modo de inserção das mulheres neste universo jurídico, História Social 7 (2000) 99-118.

Simplicio, O. D., Peccato, Penitenza, Perdono. Siena 1575-1800. La formazione della coscienza nell'Italia moderna, Franco Angeli, Milano 1994, 432 pp.

SOARES, F. N., A arquidiocese de Braga no século XVII. Sociedade e mentalidades pelas visitações pastorais - 1550-1700, Universidade do Minho, Braga 1993, $771 \mathrm{pp}$.

Thomas, K., Religion and the Decline of Magic: Studies in popular beliefs in sixteenth and seventeenth century England, Penguin Books, Harmondsworth 1973, 716 pp.

Traselli, C., Du fait divers à l'bistoire sociale. Criminalité et moralité en Sicile au debut de l'epoque moderne, Annales E.S.C. 28 (1973) 226-246.

Trindade, A. - TeIXeIRA, D., O Auditório Eclesiástico da Diocese do Funchal. Regimento e espólio documental do século XVII, Instituto Superior de Administração e Línguas, Funchal 2003, 143 pp.

ViLlalta, L. C., A torpeza diversificada dos vícios: celibato, concubinato e casamento no mundo dos letrados de Minas Gerais, 1748-1801, Master diss., São Paulo University 1993, $271 \mathrm{pp}$.

ZwI, T. T. (ed.), New Catholic Encyclopedia, New York, 14 vols. 
